\title{
RANCANG BANGUN SISTEM KOMPUTERISASI ABSENSI DAN PERHITUNGAN BONUS KARYAWAN PADA CV PERSADA ILMU
}

\author{
Andri Zulfian', Arif Susanto ${ }^{2}$, Sriyono ${ }^{3}$ \\ Program Studi Teknik Informatika, Fakultas Teknik dan Ilmu Komputer, \\ Universitas Indraprasta PGRI \\ Jalan Raya Tengah No 80, Kelurahan Gedong, Pasar Rebo, Jakarta Timur \\ andrizulfian99@gmail.com ${ }^{1}$, arif_susanto3@yahoo.com ${ }^{2}$, sriyono13@gmail.com ${ }^{3}$
}

\begin{abstract}
Abstrak
Dalam mengatasi masalah pada sebagian besar perusahaan menerapkan berbagai teknologi informasi untuk mendukung seluruh kegiatan di dalam perusahaan. Salah satu teknologi informasi tersebut adalah sistem informasi yang terdapat didalam sistem infromasi HR \& Payroll yaitu sistem informasi untuk mengolah data absensi karyawan. Sistem informasi ini sangat diperlukan untuk menghitung gaji karyawan yang nantinya berkaitan dengan laporan keuangan sebuah perusahaan. Pada CV Persada Ilmu masih di temukan kendala dalam sistem pengajian dan perhitungan bonus karyawan, seperti perhitungan gaji yang masih manual. maka diperlukan sistem yang terkomputeriasi. Pada penelitian ini, peneliti menggunakan metode Grounded Research yaitu suatu jenis penelitian berdasarkan fakta dan menggunakan analisis perbandingan. Dengan metode pengumpulan data seperti studi lapangan (observasi, wawancara) dan studi pustaka dengan mengumpulkan data-data dari buku-buku serta mencari informasi dan teori yang berhubungan dari penelitian. Hasil dari penelitian ini peneliti membuat suatu sistem aplikasi absensi dan perhitungan bonus karyawan di CV Persada Ilmu menggunkan Java dan MySQL.
\end{abstract}

Kata Kunci: Absensi, Gaji, Grounded Research, Java, MySQL

\begin{abstract}
In addressing the problem in most companies apply a variety of information technology to support all activities within the company. One of the information technology is the information system contained in the $H R \&$ Payroll information system, which is an information system to process employee attendance data. This information system is very necessary to calculate the salaries of employees who will be related to a company's financial statements. In CV Persada Ilmu still found obstacles in the system of studying and calculation of employee bonuses, such as the calculation of salaries that are still manual. computerized systems are required. In this study, researchers used Grounded Research method which is a type of factbased research and using comparison analysis. By data collection methods such as field studies (observations, interviews) and literature studies by collecting data from books and looking for information and related theories from research. As a result of this research, researchers created an attendance application system and employee bonus calculation in CV Persada Ilmu using Java and MySQL.
\end{abstract}

Keywords: Attendance, Salary, Grounded Research, Java, MySQL

\section{PENDAHULUAN}

Pada masa sekarang ini untuk menghadapi persaingan global, perusahaan-perusahaan sangat membutuhkan peranan komputer dalam mengambil suatu keputusan untu menyelesekan masalah yang ada berdasarkan pada informasi yang akurat dan dapat dipercaya. Menurut (Abdul, 2014) "Sistem informasi adalah Sebuah rangkaian prosedur formal dimana data dikelompokkan, diproses menjadi informasi, dan didistribusikan kepada pemakai". Salah satu teknologi informasi tersebut adalah sistem informasi yang terdapat didalam sistem infromasi HR \& Payroll yaitu sistem informasi untuk mengolah data absensi karyawan. Menurut (S.R, 2014) "Istilah gaji biasanya digunakan untuk pembayaran kepada pegawai yang digunakan untuk pembayaran kepada pegawai yang diberi tugas-tigas administratif dan pimpinan". Informasi ini sangat diperlukan untuk menghitung gaji karyawan yang nantinya berkaitan dengan laporan keuangan sebuah perusahaan, selain itu data absensi juga diperlukan dalam pemberian surat peringatan kepada karywan jika absensi karyawan tersebut melewati batas maksimum yang diterapkan oleh perusahaan. Oleh karena itu, data absensi karyawan harus tersimpan dengan baik didalam basis data sebuah perusahaan. Kegunaan absensi ini terjadi pada pihak karyawan, salah satu kegunaan absensi ini kepada pihak karyawan antara lain adalah dalam perhitungan kemungkinan kegunaan informasi absensi ini kepada pihak perusahaan antara lain untuk mengevaluasi kehadiaran. Pengambilan 
absensi ini manual dengan mendatangain kertas absensi dan adanya kekurangan seperti data yang tidak valid ketika data yang masuk salah dan memungkin terjadi kecurangan jam masuk ataupun jam pulang, maka dibuatkan sehingga dibuatlah perangkat lunak sistem absensi untuk mempermudah absensi dan tidak adanya kerusakan data pada absensi karyawan. Berdasarkan pada permasalahan yang peneliti jelaskan diatas maka peneliti mempunyai gagasan untuk membuat aplikasi yang dirancang berbasis java guna membantu karyawan dalam absensi secara cepat penelitian ini dilakukan sabagai bahan yang diperlukan untuk tugas sehingga aplikasi yang diusulkan tersebut diharapkan dapat membantu karyawan dalam pengabsensian pada $\mathrm{CV}$ persada ilmu.

\section{PENELITIAN RELEVAN}

Penelitian yang dilakukan oleh (Adrian, 2014) yang berjudul Sistem Informasi Absensi dan Penggajian Pegawai Honorer Dinas Kebersihan Kota Depok Menggunakan Java ini bertujuan untuk mengidentifikasi, menganalisis dan untuk merancang aplikasi absensi berbasis java untuk memudahkan dalam menghasilkan laporan absensi pada Dinas Kebersihan Kota Depok tersebut. simpulan yang diperoleh dari penelitian tersebut adalah aplikasi yang dihasilkan akan mempermudah dalam mengolah data-data karyawan sehingga menjadi lebih efektif dan efisien dalam setiap prosesnya.

Penelitian yang dilakukan oleh (Eva Zuraidah, 2019) dengan judul Perancangan aplikasi absensi siswa berbasis java netbeans. penelitian ini bertujuan membuat aplikasi untuk mempermudah pendataan secara dekstop dengan serta melihat laporan absensi yang sudah didata sebelumnya.

Penelitian yang dilakukan oleh (Brata \& Bayu Whidyanto, 2017) yang berjudul Sistem Pendukung Keputusan Penentuan Gaji Bonus Karyawan Pada Restoran KL Express Dengan Metode TOPSIS. Penelitian menggunakan metode Technique for Order Preferense by Similarity to Ideal Solution (TOPSIS), hasil pengujian dari aplikasi dengan menggunakan metode topsis mampu menyeleksi alternatif terbaik, dalam hal ini alternatif yang dimaksud yaitu karyawan yang berhak menerima gaji bonus berdasarkan kriteria-kriteria yang ditentukan. Hasil dari perhitungan manual dan sistem aplikasi adalah sama.

Penelitian yang dilakukan oleh (Saefudin, 2019) yang berjudul Sistem Pendukung Keputusan Menentukan Pemberian Bonus Tahunan Pada Karyawan Menggunakan Metode Analytical Hierarchy Process (AHP). Tujuan dilakukannya penelitian ini adalah untuk membuat sebuah sistem aplikasi pendukung keputusan untuk menentukan pemberian bonus tahunan pada karyawan menggunakan metode AHP di PT Fauzan Putra Jaya. Metode ini dipilih karena dapat menentukan nilai bobot untuk setiap atribut yang akan menyeleksi alternatif terbaik dari sejumlah alternatif lainnya, dalam hal ini alternatif yang dimaksud adalah karyawan yang direkomendasikan untuk menerima bonus tahunan berdasarkan kriteria yang telah ditentukan.

Penelitian yang dilakukan oleh (Fenny Oktavia \& Irawan, 2019) yang berjudul Perancangan Sistem Informasi Penggajian Karyawan Pada PT Sawmill Jambi. penelitian ini bertujuan memberikan solusi untuk permasalahan yang terjadi dengan menawarkan sistem informasi penggajian karyawan menggunakan bahasa pemograman PHP dan DBMS MySQL dimana peneliti melakukan pengembangan sistem dengan metode waterfall dan menggunakan pendekatan model sistem unified model language menggunakan usecase diagram, activity diagram, class diagram dan flowchart. Sistem baru menghasilkan output yang menampilkan data karyawan, data tunjangan, data bonus, data absensi yang secara terstruktur dan menampilkan laporanlaporan yang diperlukan untuk memudahkan PT. Sawmill Jambi dalam pengolahan data.

Penelitian yang dilakukan oleh (Wiajaya \& Marisa, 2018) yang berjudul Perancangan Aplikasi Penentuan Bonus Karyawan Dengan Metode Topsis. Penelitian ini menghasilkan suatu sistem informasi yang dapat membantu untuk menentukan dan menghitung setiap kriteria dalam penentuan bonus karyawanmenggunakan metode TOPSIS. Dengan adanya sistem tersebut dapat membantu pihak perusahaan untuk menentukan bonus karyawan dengan tepat dan akurat.

Penelitian yang dilakukan oleh (Nababan \& Rahim, 2018) yang berjudul Sistem Pendukung Keputusan Rewars Bonus Karyawan Dengan Metode Topsis . Penelitian ini bertujuan merancang dan membuat sistem untuk menentukan karyawan yang berhak menerima bonus kedisiplinan yang lebih baik dari sistem sebelumnya dimana masih bersifat manual, untuk itu diperlukan suatu konsep pendukung keputusan yang memudahkan memberikan keputusan pemberian reward bonus, pada penelitian ini 
menggunakan metode Technique Order Preference By Similarity To Ideal Solution (TOPSIS) dimana akan memudahkan dalam proses pengambilan keputusan.

Penelitian yang dilakukan oleh (Akhmad, 2012) yang berjudul Sistem Penggajian Pada Perusahaan Ekspedisi Muatan Kapal Laut. Penelitian ini menggunakan analisis kinerja, informasi, ekonomi, kendali, efisiensi, layanan dan analisis kebutuhan sistem. Analisis tersebut mampu mengenali kelemahan sistem penggajian yang lama dan memberikan usulan perbaikan pada subsitem; penggajian , data induk pegwai, dan administrasi trucking.

\section{METODE PENELITIAN}

Metodologi yang digunakan dalam penelitian ini adalah metode grounded (grounded research). Menurut (Sugiyono, 2013) "Metode Grounded Research yaitu suatu metode penelitian yang berdasarkan generasi empiris, menetapkan konsep, membuktikan teori, mengembangkan teori, mengumpulkan dan analisis data dalam waktu yang bersamaan. Dalam riset ini data merupakan sumber teori atau teori berdasar data, sehingga pengumpulan data yang telah dilakukan akan mendapat data-data yang akurat". Metode pengumpulan data yang dilakukan oleh peneliti diantaranya:

1) Studi kepustakaan yaitu pengumpulan data dan informasi dengan mempelajari buku dan sumber-sumber lainnya yang dapat menunjang penelitian ini

2) Studi lapangan yaitu dengan observasi, pengumpulan data dengan mengamati secara langsung terhadap suatu objek yang diteliti dan juga dengan wawancara yaitu teknik pengumpulan data yang dilakukan dengan tanya jawab dengan responden.

\section{HASIL DAN PEMBAHASAN}

Untuk mengatasi masalah tersebut, maka alternatif penyelesaiannya adalah berupaya membuat rancang bangun sistem yang dapat mengatasi masalah-masalah yang terjadi dalam data-data hasil absensi dan bonus karyawan. Aturan Bisnis Sistem yang Diusulkan:

1. Data karyawan untuk mengolah data - data karyawan untuk mempermudah administrasi yang mempermudahkan proses administrsi yang berkaitan dengan karyawan.

2. Data absensi, proses ini dilakukan untuk menghitung kehadiran karyawan dan menghitung pembonusan karyawan.

3. Rekapan absensi ini dilakukan untuk menghitung kehadiran seluruh karyawan dalam satu bulan.

4. Proses bonus karyawan akan ini dilakukan untuk mengetahui laporan pembonusan pada seluruh karyawan.

5. Data laporan Terakhir pimpinan dapat melihat dan menerima laporan kegiatan dari admin melalui sistem yang dirancang secara otomatis tanpa menggunakan sistem manul.

\section{Diagram Alir Data (DAD) Sistem yang Diusulkan (Diagram Konteks, Nol, Rinci)}

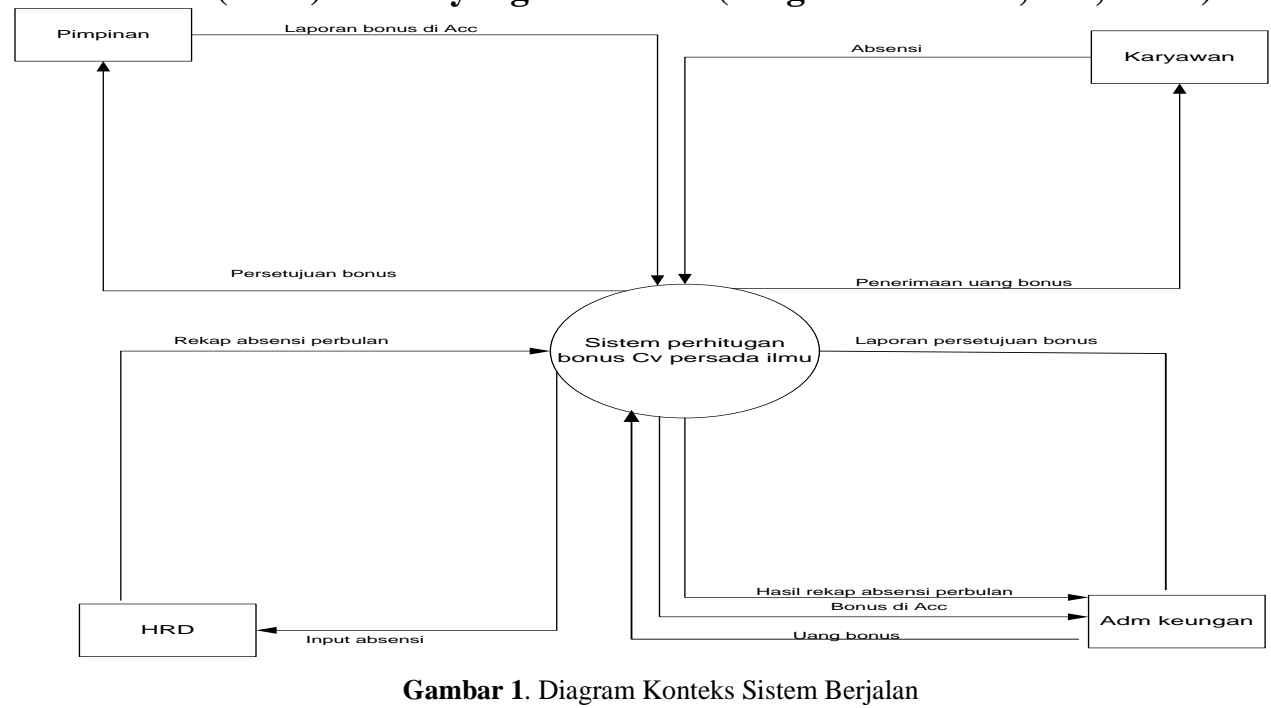

Pada diagram diatas memperlihatkan gambaran umum dari subsistem yang berjalan sistem perhitungan bonus CV Persada Ilmu, seluruh subsistem diwakili oleh satu simbol proses. Subsistem 
yang berjalan dalam perhitungan bonus di CV Persada Ilmu berinteraksi dengan kelompok pengguna yaitu karyawan, HRD, Adm Keuangan dan Pimpinan. Karyawan melakukan absensi dan menerima uang bonus. Adm Keuangan mendapatkan info hasil rekap absensi karyawan, bonus acc, admin juga membuat laporan uang bonus serta persetujuan uang bonus karyawan. HRD mendapatkan data absensi serta membuat rekap abasensi perbulan. Pimpinan menerima seluruh laporan bonus dan memberikan informasi laporan bonus yang di acc.

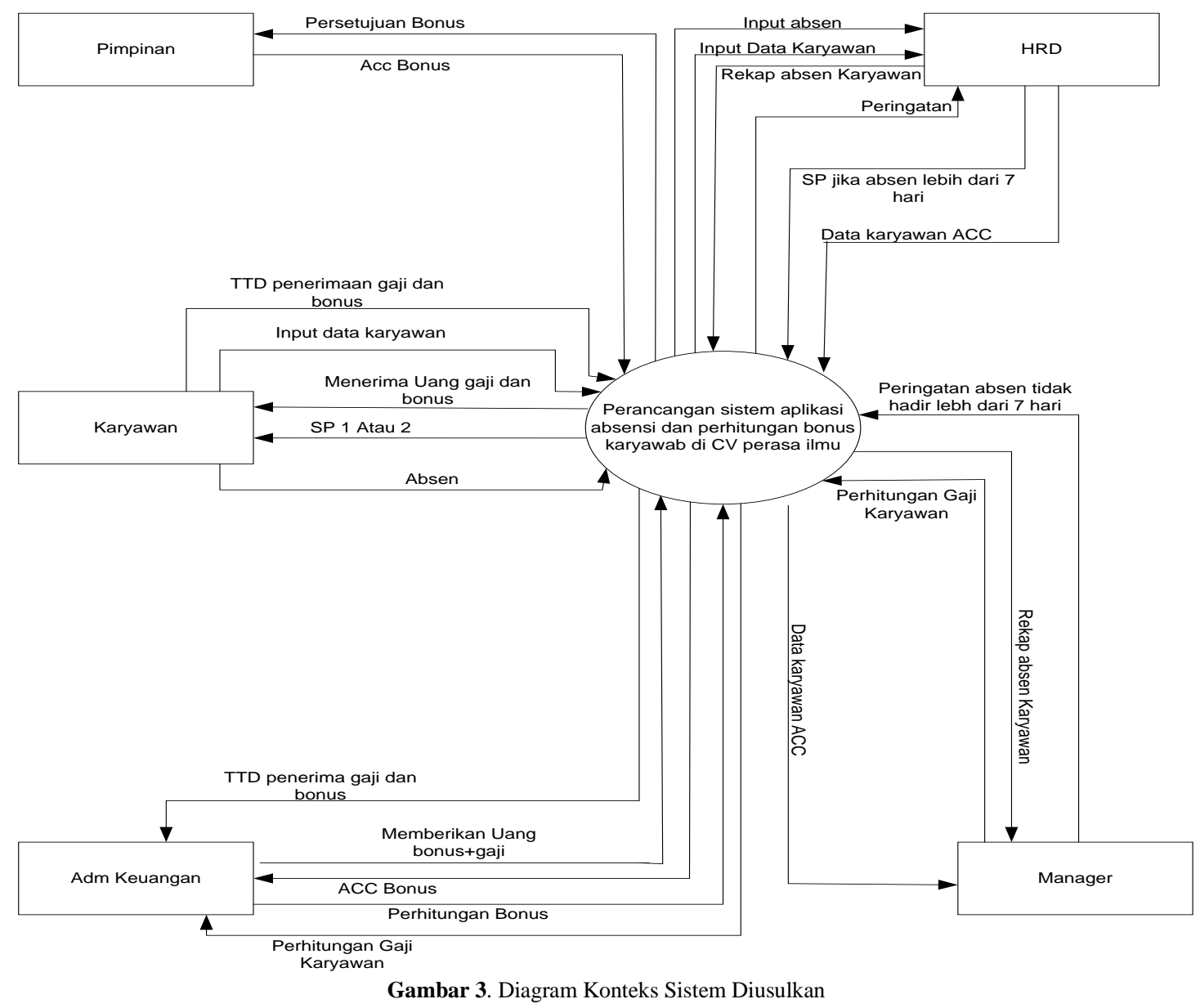

Pada diagram diatas memperlihatkan gambaran dari subsistem rancang bangun sistem absensi seluruh karyawan, Subsistem aplikasi absensi dan bonus karyawan dengan kesatuan luar atau kelompok pengguna yaitu admin keuangan,, manager, dan pimpinan , admin keuangan bisa mengakses semua data karyawan serta membuat semua laporan dari sistem absensi dan bonus karyawan. Manager dan pimpinan menerima laporan absensi dan bonus karyawan. Pimpinan dapat melihat seluruh laporan absensi dan bonus karyawan. 


\section{Entity Relationship Diagram (ERD)}

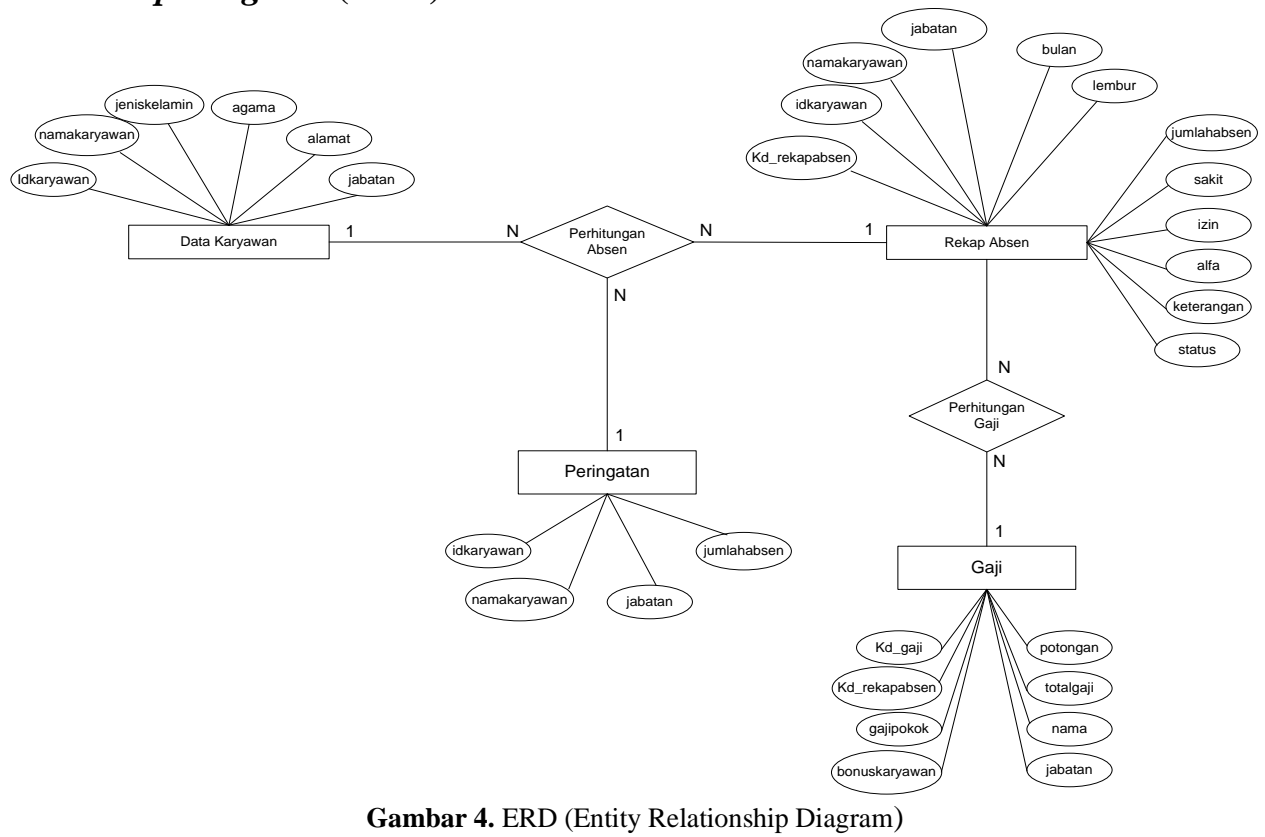

Pada gambar di atas dapat di jelaskan bahwa karyawan bisa melihat absensi, gaji, dan bonus karyawan, dan peringatan kehadiran karyawan, serta pimpinan dan manager bisa memberikan peringatan terhadap karyawan.

Tampilan Layar Sistem yang Diusulkan :

\section{Tampilan Menu Login}

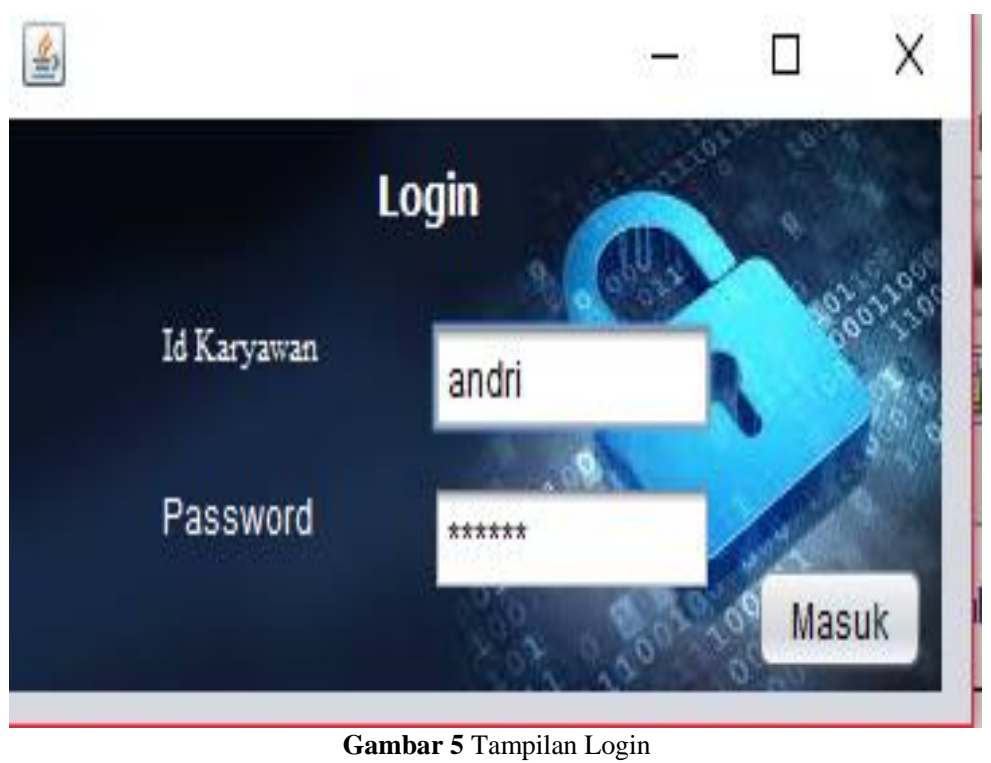

Menu login digunakan sebagai kata kunci sebelum kita memasuki menu utama. Agar tidak sembarangan orang dapat mengakses program ini. Sehingga dalam form menu kerahasiaanya dapat terjaga dengan baik. Apabila pengguna dapat memasukan username, password dan hak akses dengan tepat, maka menu utama akan tampil dan program siap untuk dijalankan. 


\section{Tampilan Layar Menu Utama}

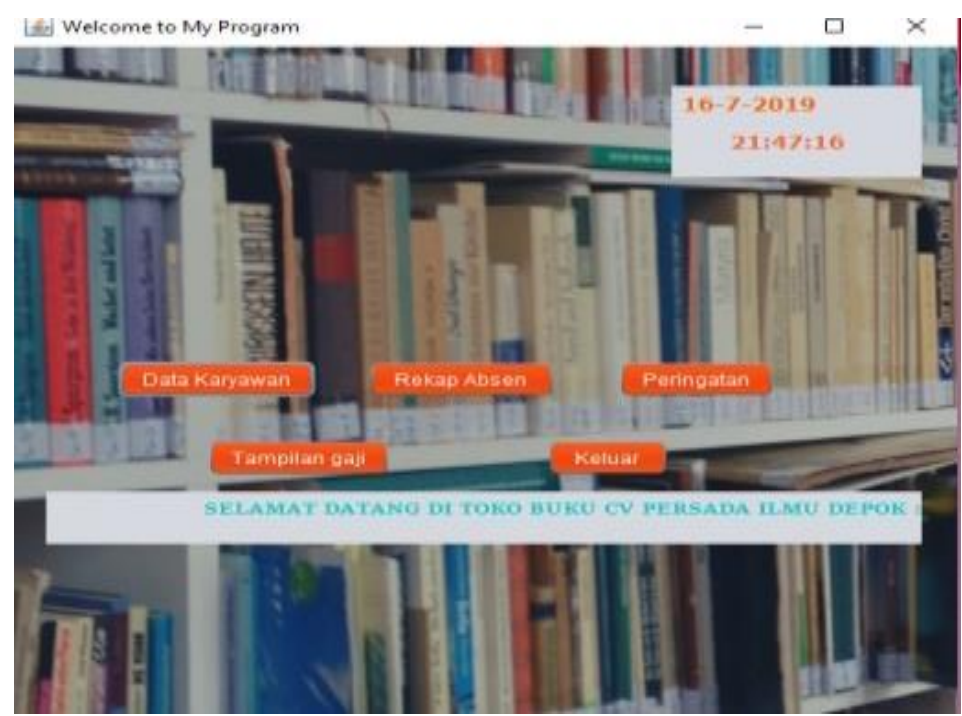

Gambar 6. Tampilan Menu Utama

Layar diatas menampilkan tampilan menu utama Absensi dan perhitungan Bonus karyawan $\mathrm{Cv}$ Persada ilmu.

\section{Tampilan Data Karyawan}

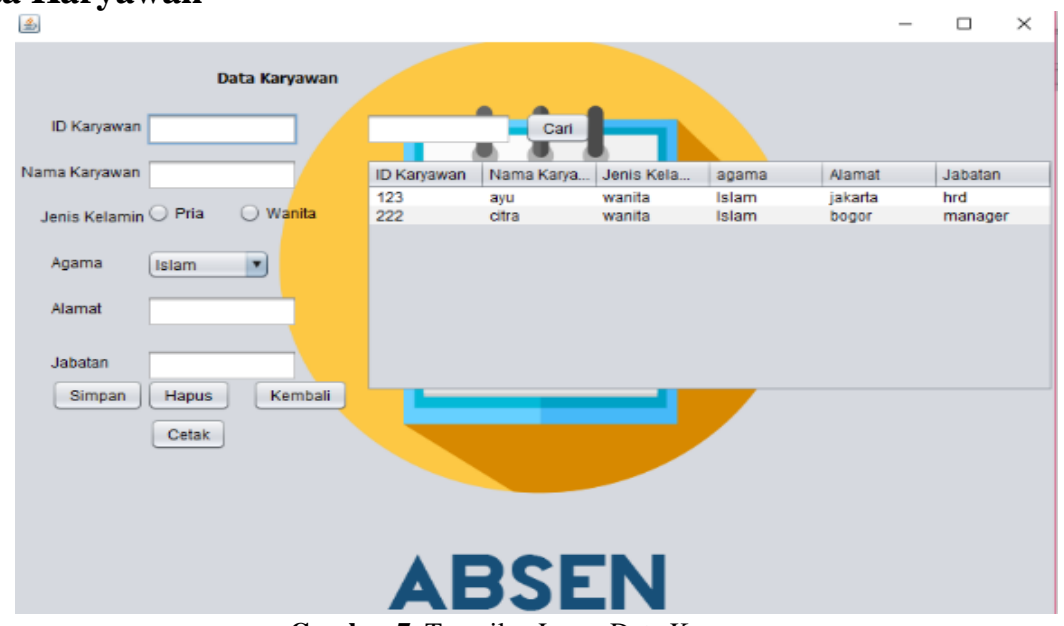

Gambar 7. Tampilan Layar Data Karyawan

Pada tampilan from data karyawan, admin dapat melakukan penambahan data karyawan, mengubah data karyawan, menghapus data karyawan, dan mencari data karyawan. Untuk menambah data pegawai makan admin harus mengisi from data pegawai, nama karyawan, jenis kelamin, agama, alamat, dan jabatan kemudian pilih tombol ok. 


\section{Tampilan Rekap Absen}

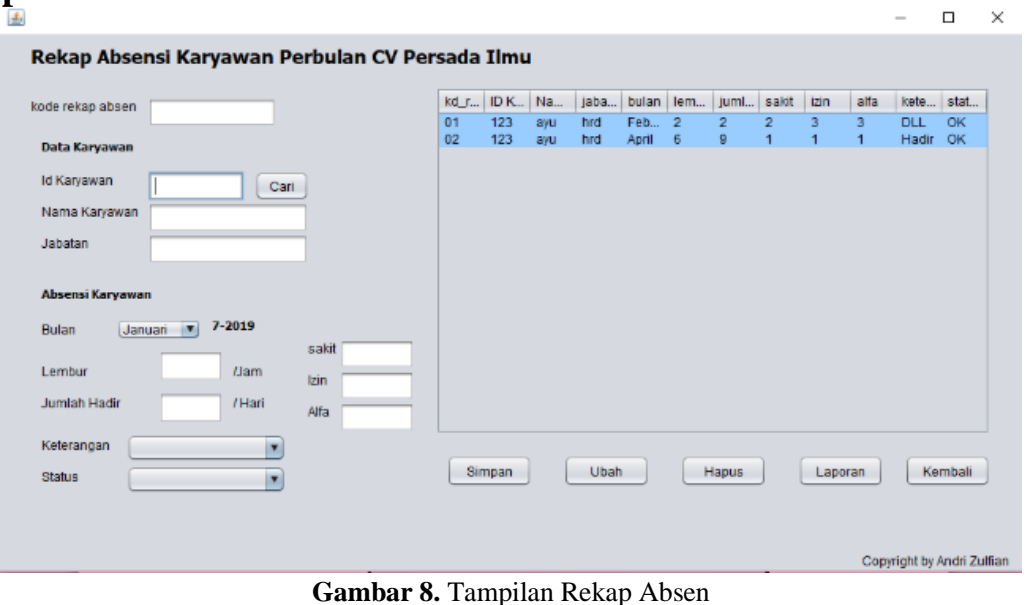

Pada tampilan form rekap abesn, admin dapat melakukan penambahan data absen, mengubah data, menghapus data.

\section{Tampilan Peringatan}

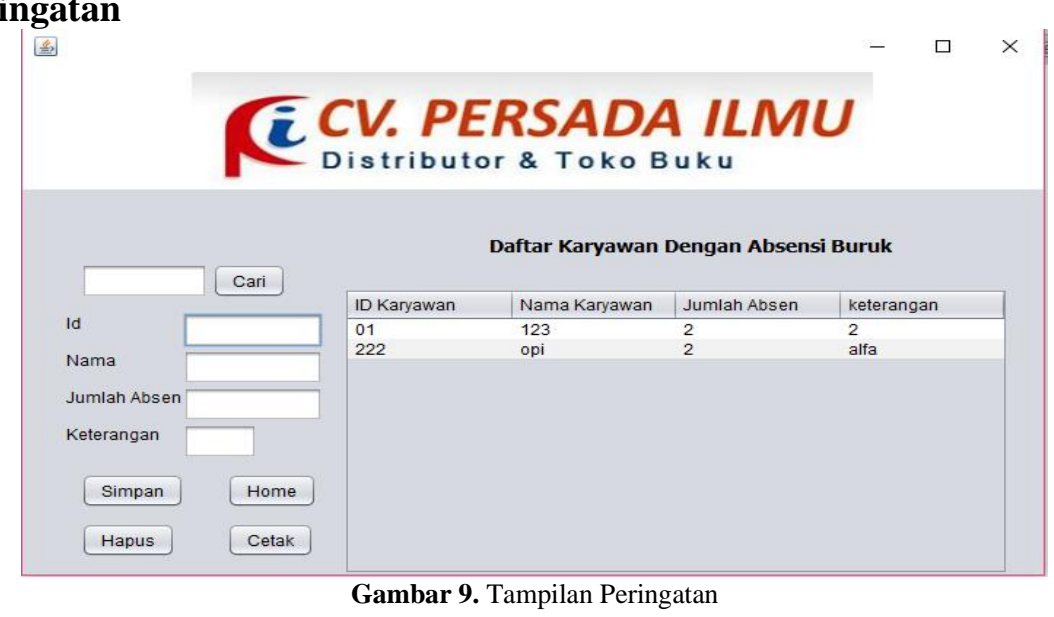

Pada form ini data absensi akan menunjukan data karyawan dengan jumlah absen yang buruk.

\section{Tampilan Gaji dan Bonus Karyawan}

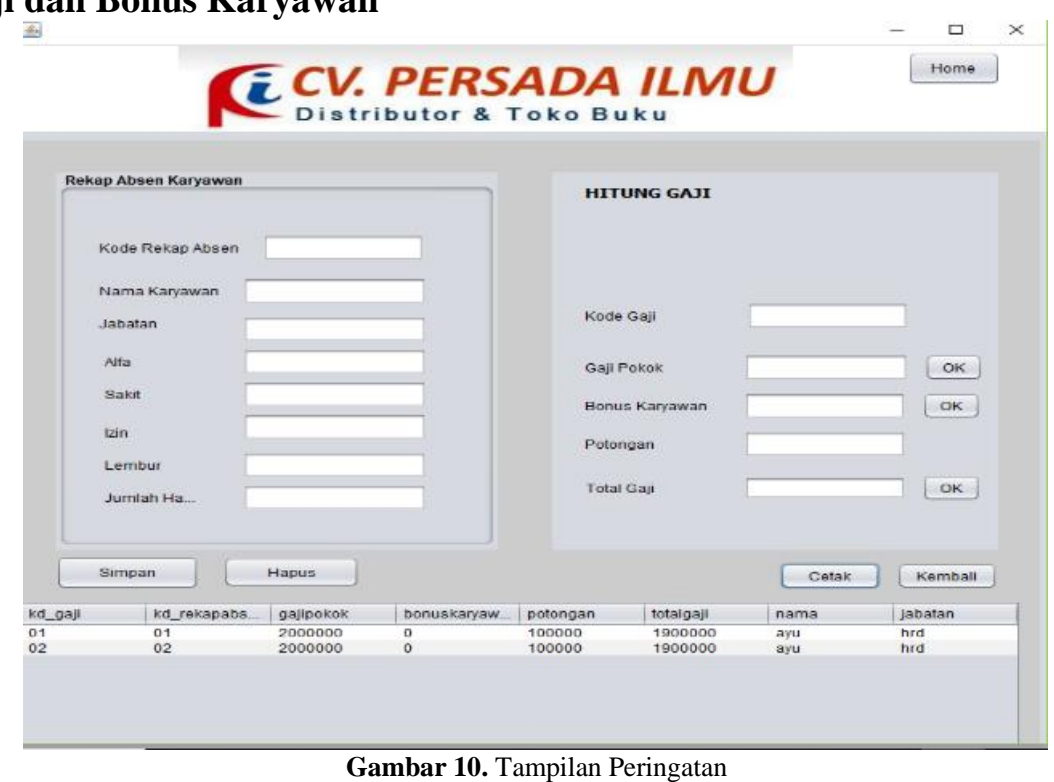

Pada form ini akan menunjukan data gaji karyawan dan bonus karyawan. 


\section{Tampilan Data Laporan}

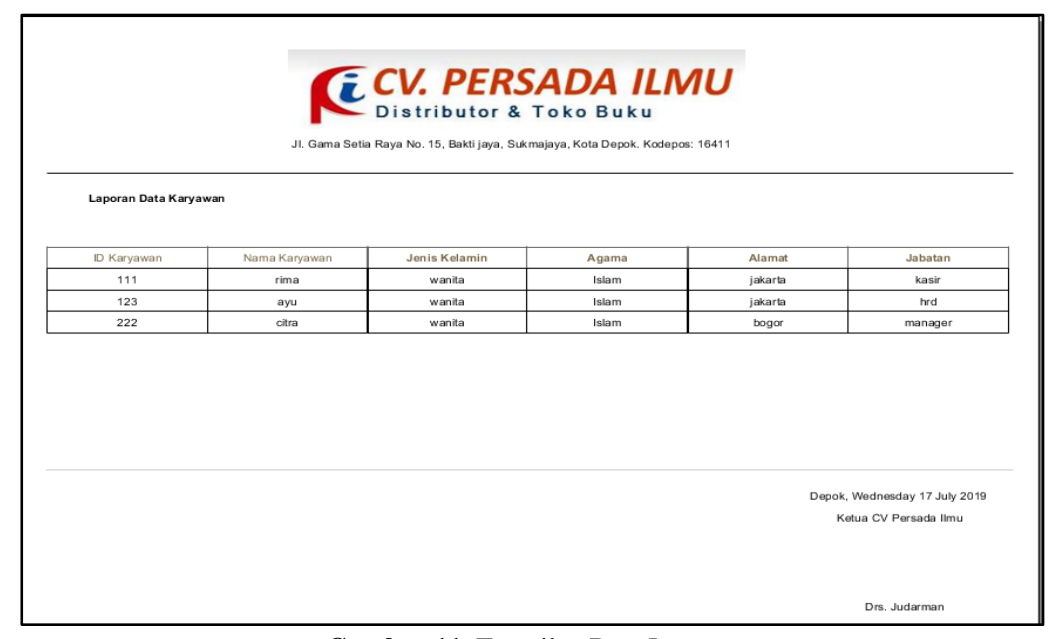

Gambar 11. Tampilan Data Laporan

Tampilan Laporan Data Laporan merupakan laporan data absensi yang dapat di cetak untuk dapat digunakan sebagai laporan kepada kepala CV.

\section{SIMPULAN}

Dari hasil pembahasan yang telah diuraikan pada bab-bab sebelumnya, maka dapat disimpulkan bahwa dengan adanya Perancangan Sistem Aplikasi Absensi dan Bonus Karyawan ini dapat memudahkan HRD dalam melakukan penginputan data absensi dan bonus karyawan yang ada di CV Persada Ilmu Depok Dengan menggunakan Perancangan Sistem Aplikasi Absensi dan Bonus Karyawan ini dapat mengefisiensikan waktu serta mempermudah HRD dalam melakukan penginputan data absensi dan bonus karyawan. Serta dengan adanya Peracangan Sistem Aplikasi Absesni dan Bonus Karyawan. data-data yang disimpan lebih terstruktur dan juga lebih aman.

\section{DAFTAR PUSTAKA}

Abdul, K. (2014). Pengenalan Sistem Informasi. yogyakarta: Andi Offiset.

Adrian, N. (2014). No Title. In Sistem Informasi Absensi dan Penggajian Pegawai Honorer Dinas Kebersihan Kota Depok. kota depok.

Akhmad, E. P. A. (2012). Sistem Penggajian Pada Perusahaan Ekspedisi Muatan Kapal Laut. Jurnal APlikasi Pelayaran Dan Kepelabuhan, Vol.2 No.2, 109-119.

Brata, D. W., \& Bayu Whidyanto. (2017). Sistem Pendukung Keputusan Penentuan Gaji Bonus Karyawan Pada Restoran KL Express Dengan Metode TOPSIS. Jurnal Ilmiah Teknologi Dan Informasi ASIA (JITIKA), Vol.11, No, 101112.

Eva Zuraidah, S. A. (2019). Perancangan Aplikasi Absensi Siswa Berbasis Java Neatbeans. Jurnal Prosisko, Vol. 6 No., 53-59.

Fenny Oktavia, A. S., \& Irawan, B. (2019). PERANCANGAN SISTEM INFORMASI PENGGAJIAN KARYAWAN PADA PT. SAWMILL JAMBI. Jurnal Ilmiah Mahasiswa Sistem Informasi, Vol 1, No., 265-277.

Nababan, D., \& Rahim, R. (2018). SISTEM PENDUKUNG KEPUTUSAN REWARD BONUS KARYAWAN DENGAN METODE TOPSIS. Jurnal ISD, Vol.3 No.1, 57-62.

S.R, S. (2014). Akuntansi Suatu Pengantar Edisi Kelima, Buku 2. Jakarta: Salemba Empat.

Saefudin, F. A. (2019). SISTEM PENDUKUNG KEPUTUSAN MENENTUKAN PEMBERIAN BONUS TAHUNAN PADA KARYAWAN MENGGUNAKAN METODE ANALYTICAL HIERARCHY PROCESS (AHP). JSiI | Jurnal Sistem Informasi, Vol. 6 No., 54-61.

Sugiyono. (2013). Metode Penelitian Kuantitatif dan $R \&$ D. Bandung: Alfabeta.

Wiajaya, V. P., \& Marisa, F. (2018). Perancangan Aplikasi Penentuan Bonus Karyawan Dengan Metode TOPSIS. (JOINTECS) Journal of Information Technology and Computer Science, Vol. 3, No, 91-94. 